\title{
Effects of plants diversity on soil bacteria load in a tropical moist forest of Otuoke, Nigeria
}

\section{Okpo Esio Unanonwi ${ }^{1}$ and Michael Adeoye Odebunmi ${ }^{2}$}

\author{
${ }^{1}$ Department Biology. Federal University Otuoke. Nigeria. Email: \\ okpoesio2002@yahoo.com. \\ ${ }^{2}$ Department of Microbiology. Federal University Otuoke. Nigeria.
}

\begin{abstract}
Most attempts towards forest management are directed towards management of forest resources which does not embrace other players. Key players in forest ecosystem are bacteria and fungi. Relationships between forests stand density and diversity with soil microbial population is an area of research that could aid in forest ecosystem management, this study was undertaken to provide the needed information. Three locations A, B, C of plot size $100 \mathrm{~m} \times 100 \mathrm{~m}$ were purposefully selected. Site A and B were selected based on species richness and heterogeneity, while $\mathrm{C}$ was based on dominance and homogeneity. These were further divided into $25 \mathrm{~m}$ x $25 \mathrm{~m}$ subplots, and finally divided into $2 \mathrm{~m} \times 2 \mathrm{~m}$ sample plots for investigation. Three of these were randomly selected from each site for identification and listing. Soil samples were collected across sites, inoculated, cultured and analyzed in the laboratory to estimate microbial population and identify microbial genera's. Species diversity were calculated using Shannon (H'), Simpson (D) and Sørensen's Coefficient (CC) indices. Bacteria and their colony forming units were calculated for sites. Results shows mean values of plant species diversity and mean values of bacteria counts were significantly $(p<0.05)$ different across the locations. Location $\mathrm{A}$ has a mean value $4.781 \pm 0.00$ for Simpson index, with mean bacteria load of 2.11 \pm 0.012 and $1.5115 \pm 0.00$ for Shannon index with very high level of diversity. Location B has moderate level of diversity with mean index of $3.675 \pm 0.00$ for Simpson, and $1.375 \pm 0.00$ for Shannon indices, with mean bacteria load $2.40 \pm 0.21$. Similarity content for locations A and B was 0.444. Plants diversity and bacteria load were positively significantly $(p<0.05)$ correlated with $r^{2}$ of $76 \%$. Increasing plants diversity will increase soil bacteria load. This would aid decisions making in forest conservation and ecosystem management.
\end{abstract}

Keywords: Plants diversity; Vegetation; Diversity indices; Ecosystem management; Tropical moist forest.
Received

February 14, 2019

Accepted

April 17, 2019

Released

April 30, 2019

Full Text Article

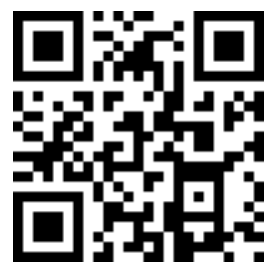

ORCID

(D) 0000-0003-1308-9131 Okpo Esio Unanonwi

(1) 0000-0002-1433-3469 Michael Adeoye Odebunmi 


\section{Introduction}

Most soil organisms are known to be plant-specific which could impinge on litter decomposition where the plant community is homogenous. Plants species diversity reduction have been reported (Loreau et al., 2001; Cardinale et al., 2007) to have negative effect on ecosystem functions such as primary productivity and nutrient cycling (Roscher et al., 2005; Cardinale et al., 2011). The functionality of terrestrial ecosystem is predicated on activities of soil organisms such as decomposition of organic matter for release of energy. This means that the amount/number of plants in a defined habitat, and the number/types of soil organisms present belowground should have impacts on ecosystem functions. Grace et al. (2007) and Nikalaus et al. (2007) ahave reported that divers' plant species communities are more productive than plant community with low biodiversity. Hooper et al. (2012) stated that microbially-driven process, such as decomposition and element cycling, are affected by plant diversity. Lamb et al. (2011) stated that plant diversity mainly affect the soil microbial function by changing the rhizodeposits and litter content of the soil which may be mediated by species identity, biomass production and soil environments.

It has been reported (Eisenhauer et al., 2010; Roscher et al., 2012) that heterogeneous plant species diversity have a high rate of soil microbial biomass due to their different root system and root exudation compared to other homogeneous plants species. Microbial communities are known to respond to the identity and diversity of carbon substrates secreted by plants roots (Grayston et al., 1997; Johnson et al. 2008; Hooper et al., 2012), and as different plant species provide different biochemical compounds and roots exudates, higher plants diversity is likely to improve the nutrition of microorganisms in the soil (Grayston et al., 1998), thus increasing their population.

Soil microorganisms are heterotrophic organisms and formed a very small fraction of the soil mass and occupy a volume of less than $1 \%$ in the upper layer of the soil (top soil) in the range of $15-30 \mathrm{~cm}$. In the tropics, microbial population is very high but decreases with soil depth (Dehlin et al., 2006; Slabbert et al., 2010). Soil microbial growth (Oger et al., 2004; Blagodatskaya et al., 2009) and activity (Nannipieri et al., 2012) can be stimulated by labile compounds (including enzymes) released by living plants roots. Consequently, how plant diversity affects roots may determine its effects on soil microbial populations. Microbial growth in soil is carbon limited and therefore, the presence of organic matter have a significance influence on microbial populations (Lynch and Whipps, 1990; Wardle, 1992) Certain species of microorganisms (mostly fungi and bacteria) have been shown to be particularly stimulated in the soil due to the release of exudates and lysates (Alexander, 1997). The variety of organic compounds released by plants has been postulated to be an influencing factor in the diversity of microorganisms in the soil of different plant species (Rovira, 1965; Trolldenier, 1967; Bolton et al., 1992).

This study investigates the effects of plants diversity on soil microbial population of a tropical moist forest soil in Federal University Otuoke.

\section{Materials and methods}

\section{Study area}

The study area is Federal University Otuoke, located at Otuoke Town in Ogbia Local Government Area of Bayelsa State, Nigeria. The area is lies within latitude 4o 51' 05.23" $\mathrm{N}$, Longitude $6^{\circ} 20^{\prime} 14.2^{\prime \prime} \mathrm{E}$ and Latitude $4^{\circ}$ $43^{\prime} 48.69^{\prime \prime} \mathrm{N}$, Longitude 60 20' 19.84" E. It is bounded to the North by Elebele Community, to the East by Emeyal 1 and 
Kolo, to the West by Onuebum and Otuogiri, and to the South by Otuaba and Ewoi Communities; all in Ogbia Local Government Area of Bayelsa State.

Otuoke Town occupies a central position in the Niger Delta Region of Nigeria. The surface is majorly drained by Otuoke Creek-Drainages System, cutting through the community from Elebele in the North, to Otuaba in the South, and emptying into Kolo Creek at Otuogidi/Ogbia-Town in the down South. Its farmlands and extended territories are drained by Ekole Creek in the West through Atubu Sub-Creek and swamp drainage system; in the East by Kolo Creek drainage system, and South East by Akoloman Creek drainage system (Allison et al., 2007).

The climate is equatorial and the vegetation is predominated by fresh water swamp vegetation observed to have mix of little freshwater vegetation and equatorial high forest, referred to as High Equatorial Swamp forest (Horsfall anf Tano, 2015).

\section{Vegetation sampling}

Three site locations A, B and C of plot size $100 \mathrm{~m} \times 100 \mathrm{~m}$ within the study area were purposefully selected. Site location A and B were selected based on plant species richness and heterogeneity while site location $\mathrm{C}$ was selected based on plants species dominance and homogeneity. These plots were further divided into $25 \mathrm{~m} \times 25 \mathrm{~m}$ subplots, the subplots were further divided into $2 \mathrm{~m} \times 2 \mathrm{~m}$ sample plots, respectively for investigation. Three sample plots of $2 \mathrm{~m} \times 2 \mathrm{~m}$ were randomly selected from each site location A and B for plants identification and listing, while three sample plots of $2 \mathrm{~m} \times 2 \mathrm{~m}$ were also randomly selected from site location $\mathrm{C}$ with homogenous plant species for identification and listing. Biodiversity levels of Plant species representatives collected were enumerated. Three indices of plant diversity were used to calculate plant species diversity namely Shannon Index $\left(\mathrm{H}^{\prime}\right)$, Simpson Index (D) and Sørensen's Coefficient Index (CC).

\section{Soil analysis}

$1 \mathrm{~kg}$ of soil sample was collected randomly from each sub-plots A, B and C (nine samples) using a soil auger from a depth of $0-30 \mathrm{~cm}$. Samples were properly homogenized and dirt, plant roots, and small stones were removed. Collected soil samples were then labeled properly with collection dates and transported intact at ambient temperature in a sterile pack sealed polythene bags to the laboratory for soil microbial analysis.

Samples were inoculated, cultured and analyzed in the Science Laboratory, Federal University Otuoke, to accurately estimate microbial population and to identify different microbial genera's.

\section{Data analyses}

Plants diversity was analyzed using three diversity indices with formulae represented below:

\section{Shannon Index $\left(\mathrm{H}^{\prime}\right)=-\sum_{i=1}^{s} P i \ln P i$.}

Where ' $P$ ' is the proportional $(n / N)$ of individuals of one particular species found $(n)$ divided by the total; number of individuals found $(N)$.

$\ln =$ the natural $\log$

$\Sigma=$ the sum of calculation

$S=$ the number of species (Magurran, 2004; Lemos et al., 2011). 


\section{Simpsons Diversity Index (D)}

$$
\text { (D) }=\frac{1}{\sum_{i=1}^{s} P i}
$$

Where $P$ is the proportion $(n / N)$ of the individuals of one particular species found $(n)$ divided by the total number of individuals found $(N)$.

$\sum=$ sum of the calculations species.(Simpson, 1994; Lemos et al., 2011 and Magurran, 2004).

(CC)

\section{Sørensen's Coefficient Index}

$$
(\mathrm{CC})=\frac{2 * \mathrm{C}}{S 1+S 2}
$$

Where $C$ is the number species which the two communities have in common, $S 1$ is the total number of species found in community $\mathrm{A}$, and $S 2$ is the total number of species found in community B (Sørensen, 1948; Magurran, 2004).

The bacteria colony forming unit (CFU/g) was calculated using the formulae:

$$
C F U / g=\frac{M \times N}{D}
$$

Where; $\mathrm{M}=$ number of colony formed, $\mathrm{N}=$ amount of sample plated on the petri dish $(1 \mathrm{ml}), \mathrm{D}=$ dilution factor.

\section{Results}

Table 1 shows that there were a total of 114 plants species in site A, while location $\mathrm{B}$ has a total plants species of 101 , and location $C$ has a total plants species of 82. It also shows that Location A has the highest plants species, followed by location $B$, while location $C$ has the lowest. A total of 297 plants species were enumerated in the study.

Table 1. Total Plants Species found in site A, B, and C.

\begin{tabular}{lccc}
\hline Location & Sub-plot & Number of species & Location total \\
\hline A & A1 & 35 & - \\
& A2 & 40 & - \\
& A3 & 39 & 114 \\
\hline B & B1 & 33 & - \\
& B2 & 19 & - \\
& B3 & 49 & - \\
\hline C & C1 & 28 & - \\
& C2 & 30 & 82 \\
\hline Total & C3 & 24 & 297 \\
\hline
\end{tabular}


Table 2. Plants species diversity for site A, B and C.

\begin{tabular}{lccc}
\hline Location & Sub-plot & Simpson Index (1/D) & Shannon Index (H') \\
\hline A & A1 & 4.154 & 1.153 \\
& A2 & 5.096 & 1.699 \\
& A3 & 5.094 & 1.699 \\
\hline B & B1 & 4.312 & 1.513 \\
& B2 & 1.973 & 0.942 \\
& B3 & 4.741 & 1.661 \\
\hline C & C1 & 1.000 & 0.000 \\
& C2 & 1.920 & 0.672 \\
& C3 & 1.000 & 0.000 \\
\hline
\end{tabular}

Table 2 shows that Simpson index of diversity for locations A and B were three to four times higher than the Shannon index for the same sub-plots. The high diversity level recorded in Table 3 for location $A$ is therefore attributed to the higher mean values of the Simpson index. The Shannon diversity index for location $\mathrm{C}$ was less than 1 , resulting to low plants diversity.
Evidently the low diversity level of location $C$ (Table 3 ) is as a result of less than 1 mean value of Shannon index (Table 2). Location $B$ has a moderate diversity level (Table 3) because the value of Shannon index for sub-plot B2 (Table 2) was less than 1. The Simpson index therefore serves a better predictor of higher plants diversity.

Table 3. Means and standard error of plants species diversity for plots A, B, C, diversity levels, bacteria count and similarity content for plots A and B.

\begin{tabular}{lccccc}
\hline Location & 1/D & H' $^{\prime}$ & CC & $\begin{array}{c}\text { Diversity } \\
\text { Level }\end{array}$ & Bacteria count \\
\hline A & $4.781 \pm 0.00$ & $1.515 \pm 0.00$ & & Very high & $2.11 \pm 0.12^{\mathrm{a}}$ \\
$\mathbf{B}$ & $3.675 \pm 0.00$ & $1.372 \pm 0.00$ & & Moderate & $2.40 \pm 0.21^{\mathrm{b}}$ \\
$\mathbf{C}$ & $1.306 \pm 0.00$ & $0.224 \pm 0.00$ & & Low & $1.43 \pm 0.11^{\mathrm{c}}$ \\
\hline \multicolumn{2}{l}{ Similarity Content A and B } & & \multirow{2}{*}{0.444} & No overlap. \\
\end{tabular}

Table 3 shows that mean values and standard error of mean of plants diversity were significantly different $(\mathrm{p}<$ 0.05 ) across the three locations. It shows that the greater the value of $1 / \mathrm{D}$ and $\left(\mathrm{H}^{\prime}\right)$ (Simpson and Shannon Indices), the higher the species diversity, and vice versa. Sample plot A has 12 individual plant species community and sample plot $\mathrm{B}$ has 14 individual plant species community. They have 6 species in common. Therefore, Sørensen's Coefficient Index (CC) $=14+12=12 / 27$ $=0.444$.

According to Sørensen's Coefficient Index, these communities do not have much overlap or similarity (Sørensen, 1948; Magurran, 2004). High diversity plant communities are likely to provide high amount of resources to decomposers communities (Tilman, 1994). This was also shown in Table 3 where mean bacteria counts were significantly different $(\mathrm{p}<0.05)$ across the three locations with location $B$ having the highest mean value. The results suggest that moderate and high plants diversity favours bacteria population while low diversity of plant species will lead to low soil microbial population. 
Table 4. Correlation between bacteria load and plant diversity in a tropical moist forest soil.

\begin{tabular}{|lcc|}
\hline & Plant & Bacteria \\
\hline Plant & 1 & \\
\hline Bacteria & 0.767858 & 1 \\
\hline
\end{tabular}

Table 4 shows a positive significant $\quad(\mathrm{P}>0.05) \quad$ correlation between bacteria load and plant diversity. The correlation coefficient $\mathrm{R}^{2}$ was 0.767858, with a coefficient of determination $\left(\mathrm{R}^{2}\right)$ of $57.4 \%$. This means that an increase in plant diversity increases soil bacteria populations in as much also as decrease in soil microbial population would likely lead to decrease in plant density and diversity. The loss of plant species in the forest ecosystem will reduce the abundance and population of soil microbes which in turn reduces the service functions of terrestrial ecosystem such as climate regulation, soil fertility and food production (Delgado-Baquerizo et al., 2016).

\section{Conclusion}

The study has shown that plant diversity correlates with soil bacteria load. This should be inculcated into forest management plans which intent is towards forest ecosystem management. It is also an area that should be considered when considering forest/soil health for a functional ecosystem. Activities that could lead to reduced soil microbial population such as application of chemical fertilizers, exposure of forest soil through clear felling, burning of forest floor litter, animal grazing on nondesignated vegetation, and soil compaction, to mention but few, should be avoided. Forest conservation to increase plant population and diversity should be taken into consideration for a better and greener environment.

\section{Conflict of interest}

The authors declare that there is no conflict of interest.

\section{References}

Alexander, M. Biodiversity on ecosystem functioning: A consensus of current knowledge. Ecology Monography, v. 74, p. 3-45, 1997.

Allison, V. J.; Yermakov, Z.; Miller, R. M.; Jastrow, J. D.; Matamala, R. Using landscape and depth gradients to decouple the impact of correlated environmental variables on soil microbial community composition. Soil Biology and Biochemistry, v. 39, no. 2, p. 505-516, 2007. https://doi.org/10.1016/ j.soilbio.2006.08.021

Balgodatskaya, E. V.; Balgodatskaya, S. A.; Anderson, T. H.; Kuzyakov, Y. Impact of artificial root exudate on the bacterial community structure in bulk soil and maize rhizosphere. Soil Biology and Biochemistry, v. 35, no. 9, p. 1105-1192, $2009 . \quad$ https://doi.org/10.1016/S00380717(03)00179-2

Bolton, H.; Frederickson, J. K.; Elliott, L.F. Microbial ecology of the rhizosphere and functional group effects on abiotic and microbial soil properties and plant soil feedback and substrate availability in soil. European Journal Soil Science, v. 60, p. 186-197, 1992.

Cardinale, B. J.; Wright, J. P.; Cadotte, M. W.; Carroll, I. T.; Hector, A.; Loreau, M.; Wiess, J. J. Impact of plant diversity on biomass production increase through time because of species complementarity. PNAS, v. 104, p.18123-18128, 2007. https://doi.org/ 10.1073/pnas.0709069104

Cardinale, B. J., Duffy, J. E.; Gonzalez, A.; Hooper, D. U.; Perrings, C. Venail, P.; Narwani, A.; Mace, G. M.; Tilman, D.; Wardle, D. A.; Kinzig, A. P.; Daily, G. C.; Loreau, M.; Grace, J. B.; Larigauderie, A.; Srivastava, D. S.; Naeem, S. Biodiversity loss and its impact on humanity. Nature, v. 486, p. 59-67, 2012. https://doi.org/10.1038/nature11148 
Cardinale, B. J.; Mahclick, K. L.; Hooper, D. U.; Byrnes, D. E.; Duffy, E.; Game Feldt, L.; Gonzalez, A. The role of producer diversity in ecosystem. American Journal of Botany, v. 98, no. 3, p. 572-572, 2011. https://doi.org/10.3732/ajb.1000364

Dehlin, H.; Nilsson, M.-C.; Wardle, D. A. Aboveground and belowground responses to quality and heterogeneity of organic inputs to the boreal forest. Oecologia, v. 150, no. 1, p. 108-118, 2006. https://doi.org/10.1007/ s00442-006-0501-5

Delgado-Baquerizo, M.; Maestre, F. T.; Riech, P. B.; Jeffries, T. C.; Gaitan, J. J.; Encinar, D.; Berdugo, M.; Campbell, C. D.; Singh, B. K. Microbial diversity drives multifunctionality in terrestrial ecosystem. Nature Communications, v. 7, article 10541, 2016. https://doi.org/10.1038/ncomms10541

Eisenhauer, N.; Beßler, H.; Engels, C.; Glexiner, G.; Habekost, M.; Milcu, A.; Partsch, S.; Sabais, A. C. W.; Scherber, C.; Steinbeiss, S.; Weigelt, A.; Weisser, W. W.; Scheu, S. Plant diversity effects on soil microorganisms support the singular hypothesis. Ecology, v. 91 no. $2, \quad$ p. $485-496, \quad 2010$. https://doi.org/10.1890/08-2338.1

Grace, J. B.; Michael, A. T.; Smith, M. D.; Seabloom, E.; Andelman, S. J.; Allain, L. K.; Jutila, H.; Sankaran, M.; Knops, J.; Ritchie, M.; Willig, M. R. Does species diversity limit productivity in natural grassland communities? Ecology Letter, v. 10, no. 8, p. 680-689, 2007. https://doi.org/ 10.1111/j.1461-0248.2007.01058.x

Grayston, S. J.; Vaughan, D.; Jones, D. Rhizosphere carbon flow in trees, in comparism with annual plants. The importance of root exudation and its impact on microbial activity and nutrient availability. Applied Soil Ecology, v. 5, no. 1, p. 29-56, 1997. https://doi.org/10.1016/ S0929-1393(96)00126-6

Grayston, S. J.; Wang, S.; Campbell, C. D.; Edward, A. C. Selective influence of plant species on microbial diversity in the rhizophere. Soil Biology and Biochemistry, v. 30, no. 3, p. 369-378, 1998. https://doi.org/10.1016/S0038-0717(97) 00124-7

Hooper, D. U.; Adair, E. C.; Cardinale, B. J.; Byrnes, D. E.; Hungate, B. A.; Matulich, K. L.; O'Connor, M. I. A global synthesis reveals biodiversity loss as a major driver of ecosystem change. Nature, v. 486, p. 105108, 2012. https://doi.org/10.1038/ nature11118

Horsfall, D. E.; Tano, D. A. Physico-chemical analysis of Otuoke soils. Journal of Environment and Earth Science, v. 5, no. 2, p. 197-205, 2015.

Johnson, D.; Phoenix, G. K.; Grime, J. P. Plant community of composition, not diversity, regulate soil respiration in grass lands. Biology Letter, v. 4, no. 4, p. 345-348, 2008. https://doi.org/10.1098/rsbl.2008.0121

Lamb, E. G.; Kennedy, N.; Siciliano, S. D. Effects of plant species richness and evenness on soil microbial community diversity and function. Plant and Soil, v. 338, no. $1 / 2$, p. 483-495, 2011. https://doi.org/ $10.1007 / \mathrm{s} 11104-010-0560-6$

Loreau, M. S.; Naeem, P.; Inchaush, J.; Bengtsson, J. P.; Grime, A.; Hector, D. U.; Hooper, M.A.; Lynch, J. M.; Whipps, J. M. Substrate flow in the rhizosphere. Plant and Soil, v. 129, no. 1, p.1-10, 2001. https://doi.org/10.1007/BF00011685

Magurran, A. E. Measuring biological diversity. Oxford, UK: Blackwell Publishing, 2004.

Nannipieri, P.; Giagnoni, L.; Renella G.; Puglisi, E.; Ceccanti, B.; Moscatelli, M. C.; Marinari, S. Soil enzymology: classical molecular approaches. Biology Fertility Soils, v. 48, no. 7, p. 743-762, 2012. https://doi.org/10.1007/s00374-012-07230

Nikalaus, P. A.; Alphei, J.; Kampichler, C.; Kandeler, E.; Korner, C.; Wohlfender, M. Interactive effects on plant species diversity and elevated $\mathrm{CO}_{2}$ on soil biota and nutrient cycling. Ecology, v. 88, no. 12, p. 3153-3163, 2007. https://doi.org/10.1890/06-2100.1

Oger, P. M.; Mansouri, H.; Nesme, X.; Dessaux, Y. Engineering root exudation of lotus towards the production of two novel carbon compounds leads to the selection of distinct microbial populations in the rhizosphere. Microbiology Ecology, v. 47, no. 1, p. 96103, 2004. https://doi.org/10.1007/s00248003-2012-9

Roscher, C.; Schumacher, J.; Gubsch, M.; Lipowsky, A.; Weigelt, A.; Buchmann, N.; Schmid, B.; Schulze, E.-D. Using plant 
functional traits to explain diversity productivity relationship. PLos ONE, v. 7, no. 5, e36760, 2012. https://doi.org/ 10.1371/journal.pone.0036760

Rovira, A. D. Plant root exudates and their influence upon soil micro-organism. In: Baker, K. F.; Snyder, W. C. (Eds.). Ecology of soil-borne pathogen: Prelude to biological control. Berkely. C.A.: University of California Press, 1965. p. 170-186.

Simpson, E. H. Measurement of biodiversity. Nature, v. 163, p. 688, 1949. https://doi.org/10.1038/163688a0

Slabbert, E.; Kongor, R. Y.; Esler, K. J.; Jacobs, K. Microbial diversity and community structure in Fynbos soil. Molecular Ecology, v. 19, p. 1031-1041, 2010. https://doi.org/ 10.1111/j.1365-294X.2009.04517.x

Sørensen, T. A method of establishing groups of equal amplitude in plant sociology based on similarity of species and it application to analyses the vegetation on Danish commons. Palaeoecology Biologiske Sskrifter, v. 5, p. 1-34, 1948.
Tilman, D.; Downing, J. Biodiversity and stability in grasslands. Nature, v. 367, p. 363365, 1994.

Trolldenier, G. Vergleick Swischen Fluorenzenz Mikro-Skopischer Direktzahlung, Plattengu Bverfahren und Meinbranfiter method bei Rhizospharenuntersuchungen. In: Graff, D.; Satchell J. E. (Eds.). Beiträge Zur Bodenbiologie. 1967. p. 59-71.

Wardle, D. A. A comparative assessment of factors which influence microbial biomass carbon and nitrogen levels in soil. Biological Reviews, v. 67, no. 3, p.321-358, 1992. https://doi.org/10.1111/j.1469-185X. 1992.tb00728.x 